\title{
PEMBERDAYAAN TOKOH MASYARAKAT DAN ADAT SEBAGAI MEDIA KOMUNIKASI HARMONIS DAN PEMBANGUNAN
}

\author{
Rosmawaty Hilderiah Pandjaitan ${ }^{1}$, Leila Mona Ganiem ${ }^{2}$ \\ ${ }^{1}$ Magister Ilmu Komunikasi Universitas Mercu Buana, Jakarta \\ ${ }^{2}$ Magister Ilmu Komunikasi Universitas Mercu Buana, Jakarta \\ rossajeffrey@gmail.com, leila.mona@merbubuana.ac.id
}

\begin{abstract}
Abstrak
Pengabdian ini dilatarbelakangi isu belum diberdayakannya tokoh masyarakat dan forum komunikasi adat sebagai media komunikasi harmonis dan pembangunan masyarakat Desa Sawarna Lebak Banten. Menggunakan metode ceramah dan focus group discusion (FGD). Bertujuan mengubah pengetahuan, kesadaran, dan kreativitas para tokoh masyarakat Desa Sawarna. Dilaksanakan pada hari Minggu, 10 Februari 2019, di desa Sawarna, Lebak Banten.

Adapun hasilnya yaitu : Satu, tingkat ketertarikan, pengertian, dan penerimaan peserta terhadap isi pesan sangat tinggi, mencapai 96,9\%. Dua, penggunaan video sebagai alat bantu penjelasan, sangat mendukung, disukai, dan menarik perhatian. Tiga, kurangnya imbalan, pengorbanan, maupun pembagian keuntungan dari pemerintah desa dan Pemda menjadi salah satu faktor penghambat bagi upaya dimaksud. Empat, tokoh adat dan forum komunikasi adat tidak dapat diberdayakan, karena belum dibentuk. Lima, menurut masyarakat Desa Sawarna, Pemerintah desa kurang transparan tentang dana Desa, kurang peduli pada pemberdayaan masyarakat desa, dan kurang perhatian secara finansial terhadap kegiatan komunitas pariwisata desa Sawarna. Enam, belum adanya BUMDes, menjadi hambatan bagi upaya pembangunan desa Sawarna. Tujuh, mayoritas peserta yang hadir belum paham arah kebijakan pembangunan sektoral dan pemberdayaan masyarakat (people empowering) desa, sebagai akibat masih adanya kesenjangan komunikasi (communication gap) dan belum adanya dialog yang baik antar masyarakat, tokoh masyarakat, pemerintah desa dan Pemda setempat.
\end{abstract}

Kata Kunci : Pemberdayaan Masyarakat, Forum Komunikasi Adat

\section{PENDAHULUAN}

Ada banyak cara Perguruan Tinggi berperan serta dalam mempersiapkan masyarakat menghadapi era industri 4.0. Salah satunya melalui kegiatan pengabdian pada masyarakat (P2M), dengan memanfaatkan ilmu pengetahuan dan teknologi, seperti ditegaskan dalam UndangUndang Republik Indonesia Nomor 12 Tahun 2012 tentang Pendidikan Tinggi, khususnya pada Bab 1 Pasal 1 tentang pengabdian kepada masyarakat. (http://sumberdaya.ristekdikti.go.id/wp- content/uploads/2016/02/uu-nomor-12-tahun-2012ttg-pendidikan-tinggi.pdf).

Demikian dengan kegiatan pengabdian ini, seperti diamanahkan dalam UU No 12 Tahun 2012 tersebut, bertujuan untuk memajukan kesejahteraan masyarakat dan mencerdaskan kehidupan bangsa. Namun tentu saja ada isu khusus yang melatarbelakangi kegiatan ini, sehingga tema yang dipilih berjudul "Pemberdayaan tokoh masyarakat dan forum komunikasi adat sebagai media komunikasi harmonis dan pembangunan masyarakat Desa Sawarna Lebak Banten".

Ekonomi, Sosial, dan Budaya 
Berikut latarbelakang dilakukannya P2M dengan tema pemberdayaan tokoh masyarakat dan adat sebagai media komunikasi harmonis dan pembangunan masyarakat Desa Sawarna Lebak Banten, yaitu : Satu, beberapa tahun ini, banyak wilayah di negara Indonesia diterpa isue konflik perpecahan akibat isu suku, agama, maupun ras. Untuk mengantisipasi agar hal tersebut tidak terjadi di lingkungan masyarakat Desa Sawarna Lebak Banten, maka perlu dilakukan pencegahan sedini mungkin, dengan memberdayakan para tokoh masyarakat dan adat mereka sebagai media komunikasi harmonis dan pembangunan masyarakat Desa Sawarna Lebak Banten.; Dua, Desa Sawarna di Kabupaten Lebak Banten, mulai ramai dikunjungi wisatawan baik dari dalam maupun luar negeri, sehingga ada kemungkinan adanya konflik perpecahan akibat isu suku, agama, maupun ras. Itulah sebabnya, dirasa perlu diantisipasi melalui cara pemberdayaan para tokoh masyarakat dan adat mereka sebagai media komunikasi harmonis dan pembangunan masyarakat Desa Sawarna Lebak Banten.; Tiga, dilatarbelakangi isu belum diberdayakannya tokoh masyarakat dan forum komunikasi adat sebagai media komunikasi harmonis dan pembangunan masyarakat Desa Sawarna Lebak Banten. Jadi adapun urgensi dan rasionalisasi kegiatan ini yaitu, pentingnya pemberdayaan tokoh masyarakat dan forum komunikasi adat sebagai cara menjaga keharmonisan dan pembangunan masyarakat desa Sawarna Lebak Banten.

Tujuan yang ingin dicapai yaitu : Satu, menjaga keharmonisan dan pembangunan masyarakat Desa Sawarna Lebak Banten, sebagai cara untuk melindungi dan mengelola nilai-nilai luhur yang berlaku, serta budaya yang menjadi kearifan lokal, maupun lingkungan hidup mereka secara lestari. Dua, mengubah persepsi, pengetahuan, kesadaran, kemampuan, maupun kreativitas para tokoh masyarakat Desa Sawarna Lebak Banten, tentang konsep media harmonis dan kreativitas cara menjaga keharmonisan dan pembangunan masyarakat desa Sawarna Lebak Banten.

Agar tujuan dapat dicapai, sekaligus sebagai solusi atas masalah yang ada, serta sebagai cara untuk untuk menambah pengetahuan, menyamakan persepsi, dan meningkatkan kreativitas masyarakat Desa Sawarna Lebak Banten, maka dilakukan tindakan sebagai berikut, yaitu : Satu, menjelasan tentang kebijakan pembangunan desa di Indonesia, sebagai solusi bagi pengetahuan dan persepsi peserta. Tujuannya, agar semua peserta paham bahwa, pembangunan tersebut merupakan proses aktivitas yang bersifat kontinu dan terencana, yang ditujukan untuk merubah dan meningkatkan kualitas kehidupan sosial ekonomi ke arah yang lebih baik dan wajar dari waktu ke waktu, diantaranya melalui pemberdayaan masyarakat (people empowering) terutama di pedesaan. Jadi penting untuk ditekankan bahwa, tokoh masyarakat dan adat juga dapat diberdayakan sebagai media harmonis dan pembangunan masyarakat Desa Sawarna Lebak Banten. Selain itu juga disampaikan bahwa, baik pemerintah maupun kelompok luar, hanyalah fasilitator, dinamisator, katalisator, mediator dan komunikator pelengkap dan penunjang harmonisasi dan pembangunan masyarakat Desa Sawarna Lebak Banten.

Dua, menjelasan tentang pemberdayaan masyarakat secara implisit, yang mengandung makna, faktor inisiatif justru berasal dan berkembang dari masyarakat sendiri. Sedangkan tokoh masyarakat, lebih berperan sebagai komunikator pembangunan yang bertindak sebagai penampung dan mempertimbangkan segala keluhan dari masyarakat, atau sebagai perpanjangan tangan pemerintah. Itulah sebabnya, tokoh masyarakat dituntut memiliki kepekaan serta kemampuan memberi respon terhadap inisiatif dan keluhan yang berasal dari tingkat bawah. Hal ini penting karena, seringkali inisiatif dan keluhan masyarakat bawah diabaikan, tidak memperoleh perhatian, sehingga banyak yang terpaksa mengambil jalan pintas, walaupun kadang-kadang cenderung merupakan pelanggaran hukum yaitu dengan melakukan pengrusakan ataupun hal-hal yang anarkhis. Jadi, pada hakikatnya partisipasi sosial mengandung makna, kerjasama antar masyarakat dan tokoh masyarakat yang sama-sama berperan dalam proses mewujudkan pembangunan, dengan pendekatan memperlakukan manusia sebagai subjek dan bukan objek pembangunan.

Tiga, menjelasan tentang pengertian komunikasi, yang menurut Effendy (1993:28), Ekonomi, Sosial, dan Budaya 1368 
hakikatnya adalah proses pernyataan antar manusia, dimana yang dinyatakan itu adalah pikiran, perasaan seseorang kepada orang lain, dengan menggunakan bahasa sebagai alat penyalurnya (Rosmawaty, 2010:5).

Empat, menjelasan tentang hubungan komunikasi dan budaya. Meminjam pendapat Edward T. Hall (Mulyana 2009) bahwa, budaya adalah komunikasi dan komunikasi adalah budaya. Hal ini penting sebab, faktanya sangat sulit membangun sikap toleran. Buktinya ada banyak kasus tragis dan menyedihkan akibat kurangnya sikap toleran diantara sesama manusia. Jadi perlu ditekankan bahwa kebudayaan hanya akan eksis jika ada komunikasi.

Lima, menjelasan tentang proses komunikasi. Seperti dikatakan oleh Joseph A.Devito (2009:23), komunikasi juga mengacu pada tindakan, baik oleh satu orang ataupun lebih, yang mengirim dan menerima pesan yang terdistrosi oleh gangguan (noise), terjadi dalam suatu konteks tertentu, mempunyai pengaruh tertentu, dan ada kesempatan untuk melakukan umpan balik (Rosmawaty, 2010:3). Hal ini penting agar peserta pengabdian paham, adalah wajar bila dalam setiap proses komunikasi pasti ada gangguan tertentu, sehingga perlu upaya berkali-kali agar gangguan tersebut dapat diminimalisir. Misalnya melalui forum komunikasi adat.

Enam, menjelasan tentang strategi, strategi komunikasi, dan dua bentuk strategi komunikasi, yaitu strategi persuasi melalui empat pendekatan utama untuk mendapatkan penerimaan melalui komunikasi, dan strategi instruksi, seperti dijelaskan Cutlip, Center, dan Broom (2006:229), yaitu mengenai empat pendekatan utama dalam strategi persuasi (membujuk), seperti strategi sanksi, Strategi Altruisme (dengan cara mengajak khalayak atau kelompok masyarakat erdialog), maupun Strategi Argumen, dan Strategi Sirkumvesi (circumvention) atau pengelakan, maupun Strategi instruksi. Penjelasan ini penting sebab, upaya untuk mendapatkan persetujuan adalah proses yang rumit, apalagi bila sumber pesan hanya punya sedikit kekuasaan atau kontrol terhadap khalayak atau kelompok masyarakat yang diajak berdialog. Selain itu, agar para tokoh masyarakat Desa Sawarna Lebak Banten menjadi terampil dalam memilih strategi komunikasi. Namun sebelum menjelaskan tentang beberapa strategi tersebut, terlebih dahulu dijelaskan tentang pengertian strategi komunikasi, seperti dijelaskan oleh Effendy (2003:301) bahwa, pada hakikatnya strategi komunikasi adalah merupakan paduan dari perencanaan (planning) dan manajemen (management) untuk mencapai satu tujuan, yang didukung oleh sebuah konsep atau teori. Selain itu juga dikutip pendapat Harold D. Lasswell, yang menjelaskan bahwa, salah satu cara terbaik untuk menerangkan kegiatan komunikasi yaitu dengan menjawab pertanyaan "Who, Says what, in which Channel, To whom, With What Effect"? Jadi, agar strategi komunikasi efektif, semua perencanaan dan sistim manajemen yang dipilih harus terintegrasi dan mampu menjawab berbagai pertanyaan dalam rumus atau formula Lasswell tersebut. Begitupun strategi komunikasi yang dipilih, juga harus dapat menunjukkan bagaimana operasionalnya secara taktis harus dilakukan. Misalnya tentang pendekatan (approach) yang akan digunakan, seperti telah dijelaskan, apakah dengan pendekatan persuasi ataukah instruksi, bisa berbeda sewaktu-waktu, bergantung kepada situasi dan kondisi. Dengan demikian, strategi komunikasi mempunyai "fungsi ganda" : (1) Menyebarluaskan pesan komunikasi yang bersifat informatif, persuasif dan instruktif secara sistematis kepada sasaran untuk memperoleh hasil yang maksimal dan optimal; sekaligus juga dapat (2) Menjembatani kesenjangan budaya (cultural gap) akibat kemudahan diperolehnya dan kemudahan dioperasionalkannya media massa yang begitu ampuh, yang jika dibiarkan akan merusak nilai-nilai budaya (Effendi, 2003:29). Di sinilah pentingnya pemberdayaan tokoh masyarakat dan forum komunikasi adat sebagai media harmonis dan pembangunan. Selain itu juga dijelaskan, pengertian strategi, agar para peserta P2M paham bahwa, strategi dapat mempengaruhi sukses atau gagalnya strategi itu sendiri pada akhirnya (Pito et al, 2006:196-197), dan pastinya "keberhasilan" yang akan diperoleh. Bagaimanapun, strategi itu sendiri selalu memiliki tujuan yaitu "kemenangan" (Putri, 2018:54).

Tujuh, menjelasan tentang teknik persuasi atau membujuk, seperti dikemukakan oleh Cutlip, Center, dan Broom (hal.228), berdasarkan hasil rekomendasi banyak hasil penelitian. Misalnya \begin{tabular}{l|l} 
Ekonomi, Sosial, dan Budaya & 1369
\end{tabular} 
tentang cara mengajak khalayak atau kelompok masyarakat berdialog untuk menentang pandangan, dengan cara mengajukan argumen (alasan) dari dua belah pihak yang pro dan kontra mengenai suatu isu. Selain itu tentang mengajak khalayak atau kelompok masyarakat yang sudah setuju dengan pendapat yang disampaikan, agar lebih diperkuat, diperbesar, dan diperlebar dampak pesan tersebut, dengan cara hanya mengajukan argumen (alasan) yang sesuai dengan pandangan penerima atau khalayak ataupun masyarakat. Begitupun tentang cara mengajak khalayak atau kelompok masyarakat yang diajak berdialog berpendidikan tinggi, maka masukan argumen (alasan) dari kedua belah pihak. Artinya, jangan buang argumen (alasan) dari pihak yang menentang, sebab jika argumen tersebut dibuang, maka dapat menimbulkan kecurigaan dan konflik. Demikian halnya terhadap khalayak atau kelompok masyarakat yang ada kemungkinan akan mendapatkan pesan persuasif yang bertentangan dengan pendapat yang sudah diajukan, maka sebaiknya gunakan "pesan dua sisi" untuk membuat khalayak atau kelompok masyarakat yang diajak berdialog membangun resistensi (antipati) terhadap pesan yang datang belakangan. Teknik persuasi ini perlu disampaikan sebagai cara untuk membangun pengetahuan dan meningkatkan keterampilan komunikasi para tokoh masyarakat dalam forum komunikasi adat masyarakat Desa Sawarna Lebak Banten. Terutama saat mengajak khalayak atau masyarakat untuk berdialog, berunding atau bermusyawarah, sehingga tokoh masyarakat dalam forum komunikasi adat dapat berfungsi sebagai media komunikasi harmonis dan pembangunan masyarakat Desa Sawarna Kabupaten Lebak Banten.

Delapan, menjelasan tentang saluran komunikasi, baik bersifat medium (tunggal) ataupun media (jamak), seperti dikemukakan oleh Cutlip, Center, dan Broom (hal.230), yaitu seperti melalui teknologi (termasuk digital atau virtual), melalui tatap muka (masih merupakan metode pertukaran informasi yang paling langsung dan kuat) yang dapat berupa komunikasi antarpribadi (cenderung lebih disukai) ataupun rapat (formal maupun informal). Selain itu juga dapat melalui pesan tertulis (komunikasi tertulis), pesan siaran (radio desa), ataupun melalui media tradisional (sendra tari ataupun pementasan lawak, gotong royong, kerja bakti, ataupun saat perayaan HUT RI).

Sembilan, penjelasan tentang hubungan (relasional) komunikasi, seperti dikemukakan oleh Cutlip, Center, dan Broom (hal.232), bahwa komunikasi terjadi di dalam konteks hubungan para komunikator, dan rentang hubungan itu mencakup hubungan dekat (intim), hubungan formal, hubungan kompetitif, dan hubungan interpersonal konfliktual dalam berbagai setting, yang juga sangat mempengaruhi proses komunikasi. Jadi, semua komunikasi relasional merefleksikan empat (4) dimensi dasar hubungan komunikasi, seperti kemunculan emosi, ketenangan, dan formalitas, misalnya senyuman, sentuhan, dan kontak mata . yang dapat disesuaikan dengan adat istiadat yang berlaku di tempat khalayak atau kelompok masyarakat yang diajak berdialog. Selain itu tentang keakraban dan kemiripan, sebagai simbol kedekatan (proximity). Kedekatan ini mampu menyampaikan pesan keakraban, daya tarik, kepercayaan, perhatian, dominasi, persuasi, dan keagresifan. Demikian halnya dengan kedekatan dan kegemaran. Misalnya, kegemaran mancing bersama antar tokoh masyarakat yang dapat dijadikan sebagai forum komunikasi adat. Termasuk dominasi ketundukan, misalnya saat mengucapkan kata-kata hormat seperti, kepada yang terhormat, ataupun saat menempatkan tokoh masyarakat dalam barisan tempat duduk, sebagai cara menunjukkan sikap hormat.

Sepuluh, menjelasan tentang prinsip-prinsip yang harus diperhatikan agar khalayak atau kelompok masyarakat yang diajak berdialog melalui forum komunikasi adat mau diajak bekerjasama, dengan menggunakan dasar pemikiran Teori Pertukaran Sosial yang dikembangkan oleh Thibaut dan Kelly, (Goldberg dan Larson, 1985:54) bahwa, interaksi antar manusia bagaikan konsep transaksi dagang, yang fokus pada pertukaran barang dan jasa. Jadi menurut teori ini, hubungan baik akan terus terjaga bila masing-masing pihak merasa diuntungkan dari hubungan tersebut, sebab pada dasarnya setiap orang akan mengharapkan sesuatu dari orang lain sebagai cara untuk memenuhi kebutuhannya. Jadi, tanggapan-tanggapan antar individu yang muncul melalui interaksi di antara mereka juga akan mencakup baik imbalan (reward),

Ekonomi, Sosial, dan Budaya 1370 
pengorbanan (cost), maupun keuntungan (profit). Apabila imbalan tidak cukup, atau bila pengorbanan melebihi imbalan dan keuntungan, maka interaksi antar individu yang terlibat di dalamnya akan terhenti dan mereka akan mengubah tingkah lakunya dengan tujuan mencapai apa yang mereka cari. Solusi ini perlu disampaikan, agar tokoh masyarakat dan forum komunikasi adat dapat diberdayakan sebagai media komunikasi harmonis dan pembangunan bagi masyarakat Desa Sawarna, Lebak, Banten. Jadi, prinsip imbalan dan keuntungan bagi para tokoh masyarakat dan forum komunikasi adat serta masyarakat desa juga harus dikemukakan, agar para tokoh masyarakat dan forum komunikasi adat dapat diberdayakan sebagai media komunikasi harmonis dan pembangunan masyarakat desa.

Sebelas, menjelasan tentang komunikasi efektif untuk komunikasi kelompok yang bersifat heterogen atau multikultural, yang dikutip dari Teori Kerja Kelompok Efektif Antarbudaya seperti dikemukakan oleh John Oetzel (Littlejohn, 2009:336), seperti adanya kesetaraan diantara partisipan (partisipasi setara), mufakat berdasarkan pengambilan keputusan, manajemen konflik yang tidak mendominasi, dan komunikasi dengan penuh hormat.

Duabelas, menjelasan tentang enam langkah proses pemecahan masalah sebagaimana dikemukakan oleh John Dewey (1910) dalam Teori Fungsional (Littlejohn, hal.344), mulai dari tahap mengungkap kesulitan, menjelaskan permasalahan, menganalisis masalah, menyarankan solusi, membandingkan alternatif dan menguji mereka dengan tujuan dan kriteria yang berlawanan, serta mengamalkan solusi yang terbaik.

Demikian antara lain beberapa solusi yang akan disampaikan kepada para tokoh masyarakat Desa Sawarna Lebak Banten. Selain sebagai solusi untuk membangun pengetahuan dan pemahaman serta persepsi, juga untuk meningkatkan kreativitas para tokoh masyarakat dalam memanfaatkan forum komunikasi adat masyarakat Desa Sawarna Lebak Banten. Misalnya tentang fungsi berdialog, berunding atau bermusyawarah antar tokoh masyarakat dalam forum komunikasi adat masyarakat Desa Sawarna Lebak Banten, dan juga tentang fungsi tokoh masyarakat dan forum komunikasi adat sebagai media komunikasi harmonis dan pembangunan masyarakat Desa Sawarna Kabupaten Lebak Banten.

\section{METODE}

\section{Langkah Solusi}

Untuk menjelaskan solusi kepada para peserta atau khalayak yang hadir, digunakan langkah solusi sebagai berikut : Satu, langkah awal, menjelaskan latarbelakang PPM dengan metode induktif, yaitu tentang kondisi pembangunan Desa Sawarna yang masih tertinggal, berdasarkan hasil penelitian terdahulu yang dilakukan oleh Yessie Sthepanie (2015) yang berjudul, Strategi Pengembangan Fasilitas Wisata Pantai Sawarna Di Kabupaten Lebak Banten.; Dua, langkah kedua, menjelaskan fokus bahasan, sebagai batasan dan peta pemahaman bersama, sehingga bahasan dapat fokus dan mendalam.; Tiga, langkah ketiga, menjelaskan maksud dan tujuan, agar dapat dipahami bersama, atau agar pemahaman sejak awal hingga akhir dapat dibangun sesuai harapan.; Empat, langkah keempat, menjelaskan manfaat, sebagai rangsangan yang memotivasi para peserta atau khalayak yang hadir, dan agar paham tentang nilai kegunaan solusi.; Lima, langkah kelima, menjelaskan solusi yang ditawarkan, dengan menggunakan alat bantu berupa slide projector dan video singkat yang menarik dan memotivasi.; Enam, langkah keenam, membuka ruang tanya jawab sebagai cara untuk menjaring permasalahan dan untuk memberikan solusi secara langsung sesuai pertanyaan yang disampaikan peserta.

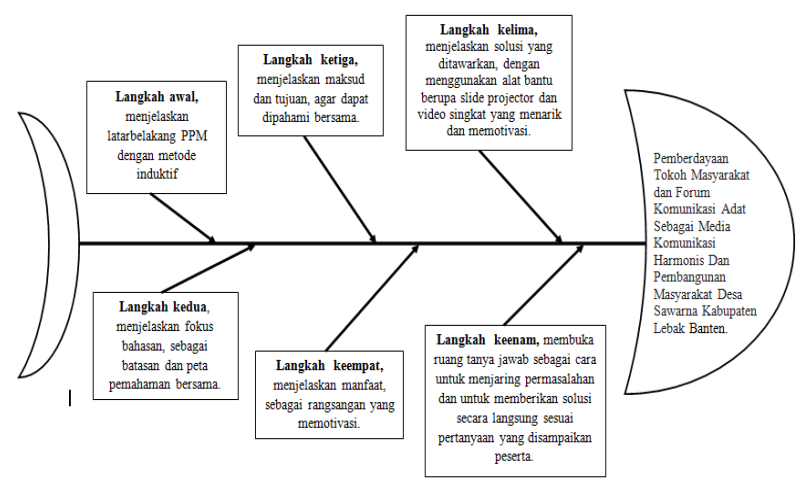

Fishbond Metode PPM Rosmawaty Hilderiah Pandjaitan

Ekonomi, Sosial, dan Budaya 


\section{Metode Pendekatan}

Agar efektif, kegiatan PPM ini menggunakan beberapa cara atau metode, dan tahapan, seperti metode ceramah, metode tanya jawab sebagai cara untuk menggali dan mendapatkan respon dari para peserta, dan metode diskusi kelompok atau focus group discusion (FGD).

\section{Langkah Evaluasi Pelaksanaan Program}

Menggunakan metode tanya jawab langsung dan kuesioner sebagai cara untuk mengukur efektifitas solusi dan tingkat pengetahuan atau pemahaman peserta (Kriyantono, 2007:59), dalam paradigma positivistik atau dengan logika deduktif (deductive logic). Namun sebagai cara untuk menjelaskan hasil interpretasi subyektif berdasarkan hasil observasi dan tanya jawab langsung dengan beberapa peserta, digunakan metode deskriptif kualitatif.

Jumlah pertanyaan yang disampaikan ada 29 soal (4 soal tentang tingkat perhatian dan ketertarikan peserta terhadap isi pesan, 21 soal tentang tingkat pengertian, dan 20 soal tentang tingkat penerimaan isi pesan). Untuk mendapatkan jawaban yang tegas, digunakan Skala Guttman, dengan jawaban "Ya-Tidak" dan "Mengerti-Tidak Mengerti" (Sugiyono,p.96), dimana jika positif = 2 dan jika negatif $=0$. Untuk membedakan responden, digunakan skala nominal atau kode (bukan nilai), seperti $\mathrm{X}$ untuk peserta masuk kategori masyarakat biasa, dan Y untuk peserta masuk kategori tokoh masyarakat.

Teknik pengambilan sampel, digunakan teknik probability sampling (peluang sama bagi semua) dengan teknik Proportionate Stratified Random Sampling, yaitu penentuan sampel dengan memperhatikan strata (tingkatan) responden dalam populasi, seperti peran sosial dalam masyarakat Desa Sawarna, termasuk latar belakang pendidikan.

Untuk menentukan ukuran sampel digunakan rumus Slovin, dimana tingkat kesalahan yang ditoleran $=10 \%$. Adapun cara mengambil jumlah sample berdasarkan masing-masing bagian, ditentukan kembali dengan rumus $\mathrm{n}=$ (populasi kelas / jumlah populasi keseluruhan) $\mathrm{x}$ jumlah sampel yang ditentukan, seperti diformulasikan sebagai berikut :

$$
\mathbf{n}=\frac{\mathrm{N}}{1+\mathrm{Ne}^{2}}
$$

Keterangan Rumus :

$\mathrm{n}=$ Jumlah sampel

$\mathrm{N}=$ Jumlah populasi

e = kelonggaran ketidaktelitian karena

kesalahan pengambilan sampel yang masih dapat ditolerin, dalam persentase yang ditetapkan adalah $10 \%=0,1$

Jadi, karena semua peserta yang hadir ada 21 orang, maka $\mathbf{N}$ atau jumlah populasi ada 21 . Sedangkan $\mathbf{n}$ atau jumlah sampel ada 17. Sedangkan teknik penarikan sampel, digunakan teknik pengambil sampel non-probabilitas berdasarkan strata atau sampel berstrata. Alokasi ukuran sampel, digunakan alokasi proporsional/alokasi perbandingan. Sebagai cara pengukuran variabel, digunakan teknik skala Likert. Jadi, untuk sampel masyarakat atau $X=12 / 20$ X 17 $=10$, dan untuk sampel tokoh masyarakat atau $\mathbf{Y}=$ $9 / 20$ X $17=7,7$ dibulatkan 8. Maka diperoleh keseluruhan sampel kelas $=10+8=18$.

Mengenai teknik analisis data, digunakan statistik inferensial atau statistik induktif, sebagai upaya untuk mengadakan penarikan kesimpulan dan membuat keputusan berdasarkan analisis yang telah dilakukan, dimana hasil analisis terhadap sampel digeneralisasikan terhadap populasi. Berdasarkan jenis analisisnya, statistik inferensial terbagi dua yaitu, analisis korelasional dan analisis komparasi. Dalam hal ini digunakan analisis korelasional, karena berusaha mencari hubungan atau pengaruh antar dua variabel, yaitu hubungan antara Variabel $X=$ Isi Pesan Sosialisasi terhadap Variabel Y=Tingkat Pemahaman, yang merupakan operasional variabelnya.

Sebagai indikator untuk variabel X yaitu : (1). Isi pesan dapat dipahami.; (2). Isi pesan menarik.; (3). Isi pesan penting.; (4). Isi pesan menambah pengetahuan.; (5). Isi pesan mengubah 
pengetahuan.; (6). Isi pesan mengubah sikap.; dan (7). Isi pesan mengubah perilaku.

Sebagai indikator untuk variabel Y yaitu : (1). Maksud dan tujuan kegiatan.; (2). Pengertian komunikasi dan hubungannya dengan pembangunan dan budaya.; (3). Pemahaman dan manfaat strategi komunikasi bagi pemberdayaan tokoh masyarakat dan forum komunikasi adat sebagai media harmonis dan pembangunan masyarakat desa Sawarna Kabupaten Lebak Banten.; (4). Pemahaman dan manfaat teknik komunikasi bagi pemberdayaan tokoh masyarakat dan forum komunikasi adat sebagai media harmonis dan pembangunan masyarakat desa Sawarna Kabupaten Lebak Banten.; (5). Pemahaman dan manfaat saluran komunikasi bagi pemberdayaan tokoh masyarakat dan forum komunikasi adat sebagai media harmonis dan pembangunan masyarakat desa Sawarna Kabupaten Lebak Banten.; (6). Pemahaman dan manfaat hubungan komunikasi bagi pemberdayaan tokoh masyarakat dan forum komunikasi adat sebagai media harmonis dan pembangunan masyarakat desa Sawarna Kabupaten Lebak Banten.; dan (7). Pemahaman prinsip-prinsip komunikasi efektif untuk mengatasi hambatan pemberdayaan tokoh masyarakat dan forum komunikasi adat sebagai media harmonis dan pembangunan masyarakat desa Sawarna Kabupaten Lebak Banten.

Adapun untuk mengukur derajat hubungan antar variabel atau untuk validitas digunakan rumus korelasi Pearson Product Moment. (Sugiyono, 2013:241).

\section{Keberlanjutan Program}

Mengingat jarak lokasi kegiatan begitu jauh, maka program ini hanya bersifat temporari, tetapi hasilnya dapat diterapkan untuk jangka panjang. Namun untuk keberlanjutannya, program ini menuntut kreativitas dan kesepakatan bersama. Baik antar tokoh masyarakat termasuk para pemuka adat Desa Sawarna, maupun antar pejabat Desa Sawarna, seperti Kepala Desa dan para perangkat desa lainnya. Hal ini penting karena, kegiatan ini juga membutuhkan biaya, sehingga butuh dukungan dana dari pejabat desa Sawarna.

\section{Realisasi Biaya}

Realisasi peruntukkan anggaran tidak sesuai dengan rencana yang telah disusun. Namun jumlah besaran pengeluaran tetap sama. Adapun penyebabnya yaitu, jumlah peserta yang hadir tidak sesuai dengan perencanaan, adanya biaya akomodasi serta konsumsi bagi penyelenggara kegiatan yang diluar biaya perkiraan, dan adanya perbedaan realisasi biaya untuk transportasi.

\section{Tempat dan Waktu Kegiatan}

Kegiatan P2M ini telah dilaksanakan pada hari Minggu, 10 Februari 2019, dari pk. 13.0015.15 wib. Bertempat di Andrew Batara Homestay, Jl. Cisuji 2 desa Sawarna Lebak, Banten

\section{HASIL DAN PEMBAHASAN}

Untuk mendeskripsikan hasil PKM ini, digunakan data hasil survey melalui kuesioner terhadap duapuluh peserta (lihat Gambar 1.), yang dibagi berdasarkan peran sosial dan latar belakang pendidikan, bukan berdasarkan jenis kelamin, sebab semua peserta yang hadir adalah lelaki, seperti tampak pada Tabel 1. dan Tabel 2.

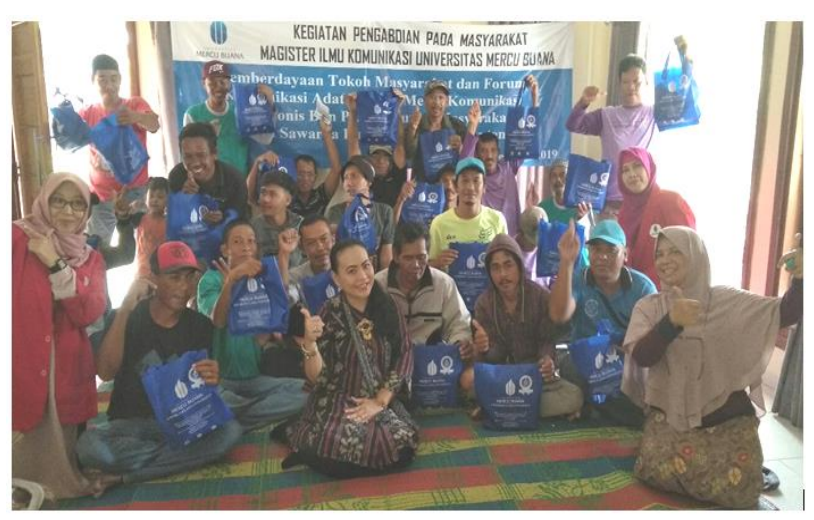

Gambar 1. Foto Bersama Setelah Acara PKM Selesai Dilaksanakan Sumber : Milik Pribadi Fasilitator (Rosmawaty Hilderiah Pandjaitan, 2019) 
Tabel 1.

Jumlah Responden Berdasarkan Peran Sosial Dalam Masyarakat Desa Sawarna

\begin{tabular}{c|c|c|c|c|c|}
\hline No & Responden & Kode & Jumlah & Sampel Responden & Presentase \\
\hline 1. & Tokoh Masyarakat & Y & 9 & 8 & $44,4 \%$ \\
2. & Masyarakat & $\mathrm{X}$ & 12 & 10 & $55,6 \%$ \\
\multicolumn{2}{c}{ Jumlah : } & & 21 & 18 Responden & $100 \%$ \\
\hline
\end{tabular}

Sumber : Diolah dari data PPM Rosmawaty, 2019

Tabel 2.

Jumlah Responden Berdasarkan Latar Belakang Pendidikan

\begin{tabular}{c|c|c|c|c|c|}
\hline No & Pendidikan Responden & Kode & Jumlah & Sampel Responden & Presentase \\
\hline 1. & SD & 1 & 9 & 8 & $44,5 \%$ \\
2. & SLTP & 2 & 5 & 4 & $22,2 \%$ \\
3. & SLTA & 3 & 5 & 4 & $22,2 \%$ \\
4. & S1 & 4 & 2 & 2 & $11,1 \%$ \\
& Jumlah : & 21 & 18 Responden & $100 \%$ \\
\hline
\end{tabular}

Sumber : Diolah dari data PPM Rosmawaty Hilderiah Pandjaitan, 2019

Dari Tabel 2 dapat dilihat, mayoritas peserta yang hadir memiliki latarbelakang pendidikan SD. Sedangkan sarjana hanya dua orang saja, selebihnya, lima orang berpendidikan SLTP, dan lima orang berpendidikan SLTA.

Namun tingkat perhatian dan ketertarikan mereka terhadap isi pesan sosialisasi sangat tinggi, mencapai 96,9\%, seperti tampak pada Tabel 3.

Tabel $\beta$.

Tingkat Perhatian dan Ketertarikan Peserta Terhadap Isi Pesan Sosialisasi

\begin{tabular}{|c|c|c|c|c|c|c|}
\hline \multirow{2}{*}{ No } & \multirow{2}{*}{ Responden } & \multirow{2}{*}{$\begin{array}{c}\text { Kode } \\
\text { Soal }\end{array}$} & \multicolumn{3}{|c|}{ Respon Terhadap Stimulus } & \multirow{2}{*}{$\begin{array}{c}\text { Total } \\
\text { Respon }\end{array}$} \\
\hline & & & $\mathrm{Ya}(\%)$ & Tidak (\%) & Tidak Jawab (\%) & \\
\hline \multirow[t]{4}{*}{1.} & Tokoh & 1 & $100 \%$ & 0 & 0 & $8=44,4 \%$ \\
\hline & Masyarakat & 2 & $100 \%$ & 0 & 0 & \\
\hline & & 3 & $87,5 \%$ & 0 & $12,5 \%$ & \\
\hline & & 4 & $87,5 \%$ & 0 & $12,5 \%$ & \\
\hline \multirow[t]{5}{*}{2.} & Masyarakat & 1 & $100 \%$ & 0 & 0 & $10=55,6 \%$ \\
\hline & & 2 & $100 \%$ & 0 & 0 & \\
\hline & & 3 & $100 \%$ & 0 & 0 & \\
\hline & & 4 & $100 \%$ & 0 & 0 & \\
\hline & Jumlah : & & $96,9 \%$ & 0 & $3,1 \%$ & $18=100 \%$ \\
\hline
\end{tabular}

Sumber : Diolah dari data PPM Rosmawaty Hilderiah Pandjaitan, 2019

Demikian halnya tingkat pengertian peserta terhadap isi pesan sosialisasi. Meski ada 1,9\% yang menjawab tidak mengerti dan 1,1\% yang tidak memberikan jawaban, namun yang menjawab mengerti tetap tinggi, yaitu mencapai $97 \%$, seperti tampak pada Tabel 4.

Adapun hasil lain yang diketahui dari kuesioner yaitu tentang respon terbuka peserta. Meski tidak semua peserta memberikan respon terbuka, namun respon yang diterima semua bernilai positif. Berikut respon yang masuk : Pertama, respon terbuka dari tokoh masyarakat (Y) yaitu : Satu, materi dan penjelasan yang disampaikan menarik sebab, menambah pengetahuan, cara penyampaian bisa dimengerti, sangat menarik dan dapat dipahami. Selain itu, solusi yang disampaikan menarik sebab, menambah ilmu, semua mufakat, menarik penampilannya, bermanfaat, dan bahasa sangat dipahami. Demikian halnya mengenai video yang disampaikan juga menarik sebab, membuka pengetahuan tentang topik permasalahan dan membuat pengetahuan menjadi lebih jelas, dan penyampaian menjadi sangat dipahami dan jelas sekali. Begitupun diskusi yang sudah dilakukan direspon menarik sebab, sangat menarik sekali penyampaiannya bagus dan diterangkan secara jelas, serta karena yang didiskusikan tentang kemajuan desa.; Dua, adapun pengertian yang dipahami oleh peserta yaitu, tokoh masyarakat dan forum komunikasi adat harus diberdayakan sebagai media komunikasi harmonis dan pembangunan masyarakat desa Sawarna Kabupaten Lebak Banten agar tidak ketinggalan. Namun sayangnya hanya sebagian cara yang dimengerti tentang cara pemberdayaan tersebut. Itulah sebabnya, menurut peserta, tokoh masyarakat dan adat harus paham dan sabar pada proses komunikasi, karena tokoh masyarakat sebagai penyalur aspirasi, yang memberikan contoh kesabaran serta keramahan. Selain itu juga dipahami oleh mereka bahwa, tokoh masyarakat dan adat harus kreatif dalam memilih saluran komunikasi, seperti bisa membedakan mana yang baik dan tidak baik, dan harus punya strategi komunikasi, seperti strategi persuasi dan instruksi untuk mengayomi. Selain itu juga harus paham, prinsip pertukaran sosial (social exchange) supaya saling melengkapi, dan prinsip kerja kelompok supaya bisa tercapai dan sukses, serta langkah proses pemecahan masalah supaya tidak ada perpecahan.; Tiga, peserta setuju dengan materi dan penjelasan yang disampaikan karena, menambah wawasan, contoh mudah dimengerti, contoh yang

Ekonomi, Sosial, dan Budaya 1374 
disampaikan bersifat edukasi, menambah atau meningkatkan ilmu pengetahuan, meningkatkan penghasilan perekonomian, bersatu dan bermasyarakat, solusi sebagai pengayom masyarakat, supaya sukses pembangunan dan persatuan, supaya masalah bisa dipecahkan, supaya bisa sukses, supaya bisa lebih dekat, dan supaya bisa menjaga kelestarian budaya, karena komunikasi alat memecah masalah.

Begitu juga halnya dengan penerimaan peserta akan isi pesan sosialisasi, juga tinggi, yaitu mencapai 98,3 \%, Untuk lebih jelasnya dapat dilihat pada Tabel 5 .

Tzbel 4

Tingkat Pergartian Peserta Terhadan Iai Peam Sosjaliagaj

\begin{tabular}{|c|c|c|c|c|c|c|}
\hline \multirow{2}{*}{$\mathrm{N}$} & \multirow{2}{*}{ Responden } & \multirow{2}{*}{$\begin{array}{l}\text { Kode } \\
\text { Soal }\end{array}$} & \multicolumn{3}{|c|}{ Respon Terbodap Stimulus } & \multirow{2}{*}{$\begin{array}{l}\text { Total } \\
\text { Respon }\end{array}$} \\
\hline & & & $\mathrm{Ya}(\%)$ & Tidak (\%) & Tidek Javab (\%) & \\
\hline \multirow[t]{21}{*}{1.} & Tokoh & $\mathrm{T}$ & $100 \%$ & 0 & 0 & \\
\hline & Masyarakat & 2 & $100 \%$ & 0 & 0 & \\
\hline & & 3 & $87,5 \%$ & 0 & $12,5 \%$ & \\
\hline & & 4 & $87,5 \%$ & 0 & $12,5 \%$ & \\
\hline & & 5 & $100 \%$ & 0 & 0 & \\
\hline & & 6 & $100 \%$ & 0 & 0 & \\
\hline & & 7 & $100 \%$ & 0 & 0 & \\
\hline & & 8 & $100 \%$ & 0 & 0 & \\
\hline & & 9 & $87,5 \%$ & $12,5 \%$ & 0 & \\
\hline & & 10 & $100 \%$ & 0 & 0 & $8=44,4 \%$ \\
\hline & & 11 & $100 \%$ & 0 & 0 & \\
\hline & & 12 & $100 \%$ & 0 & 0 & \\
\hline & & 13 & $87,5 \%$ & $12.5 \%$ & 0 & \\
\hline & & 14 & $87,5 \%$ & $12,5 \%$ & 0 & \\
\hline & & 15 & $100 \%$ & 0 & 0 & \\
\hline & & 16 & $100 \%$ & 0 & 0 & \\
\hline & & 17 & $100 \%$ & 0 & 0 & \\
\hline & & 18 & $87,5 \%$ & $12,5 \%$ & 0 & \\
\hline & & 19 & $100 \%$ & 0 & 0 & \\
\hline & & 20 & $100 \%$ & 0 & 0 & \\
\hline & & 21 & $100 \%$ & 0 & 0 & \\
\hline \multirow[t]{22}{*}{2.} & Masyarakat & 1 & $100 \%$ & 0 & 0 & \\
\hline & & 2 & $100 \%$ & 0 & 0 & \\
\hline & & 3 & $100 \%$ & 0 & 0 & \\
\hline & & 4 & $100 \%$ & 0 & 0 & \\
\hline & & 5 & $90 \%$ & 0 & $10 \%$ & \\
\hline & & 6 & $90 \%$ & $10 \%$ & 0 & \\
\hline & & 7 & $100 \%$ & 0 & 0 & \\
\hline & & 8 & $100 \%$ & 0 & 0 & \\
\hline & & 9 & $100 \%$ & 0 & 0 & \\
\hline & & 10 & $100 \%$ & 0 & 0 & $10=55,6 \%$ \\
\hline & & 11 & $90 \%$ & $10 \%$ & 0 & \\
\hline & & 12 & $100 \%$ & 0 & 0 & \\
\hline & & 13 & $100 \%$ & 0 & 0 & \\
\hline & & 14 & $100 \%$ & 0 & 0 & \\
\hline & & 15 & $90 \%$ & 0 & $10 \%$ & \\
\hline & & 16 & $90 \%$ & $10 \%$ & 0 & \\
\hline & & 17 & $100 \%$ & 0 & 0 & \\
\hline & & 18 & $100 \%$ & 0 & 0 & \\
\hline & & 19 & $100 \%$ & 0 & 0 & \\
\hline & & 20 & $100 \%$ & 0 & 0 & \\
\hline & & 21 & $100 \%$ & 0 & 0 & \\
\hline & Jumlah: & & $97 \%$ & $19 \%$ & $1,19 \%$ & $18=100 \%$ \\
\hline
\end{tabular}

Tabel 5. Tingkat Penerimann Peserta Akan Isi Pesan Sosialisasi

\begin{tabular}{|c|c|c|c|c|c|c|}
\hline \multirow{2}{*}{$\mathrm{N}$} & \multirow{2}{*}{ Responden } & \multirow{2}{*}{$\begin{array}{l}\text { Kode } \\
\text { Soal }\end{array}$} & \multicolumn{3}{|c|}{ Respon Terbadap Stimulus } & \multirow{2}{*}{$\begin{array}{l}\text { Total } \\
\text { Respon }\end{array}$} \\
\hline & & & $\mathrm{Ya}(\%)$ & Tidak $(\%)$ & Tiok Jamab (\%) & \\
\hline \multirow[t]{20}{*}{1.} & Tokoh & $T$ & $62,5 \%$ & 0 & $37,5 \%$ & \\
\hline & Masyarakat & 2 & $100 \%$ & 0 & 0 & \\
\hline & & 3 & $100 \%$ & 0 & 0 & \\
\hline & & 4 & $100 \%$ & 0 & 0 & \\
\hline & & 5 & $100 \%$ & 0 & 0 & \\
\hline & & 6 & $100 \%$ & 0 & 0 & \\
\hline & & 7 & $100 \%$ & 0 & 0 & \\
\hline & & 8 & $100 \%$ & 0 & 0 & \\
\hline & & 9 & $100 \%$ & 0 & 0 & \\
\hline & & 10 & $100 \%$ & 0 & 0 & $8=44,4 \%$ \\
\hline & & 11 & $100 \%$ & 0 & 0 & \\
\hline & & 12 & $100 \%$ & 0 & 0 & \\
\hline & & 13 & $100 \%$ & 0 & 0 & \\
\hline & & 14 & $100 \%$ & 0 & 0 & \\
\hline & & 15 & $100 \%$ & 0 & 0 & \\
\hline & & 16 & $100 \%$ & 0 & 0 & \\
\hline & & 17 & $100 \%$ & 0 & 0 & \\
\hline & & 18 & $100 \%$ & 0 & 0 & \\
\hline & & 19 & $100 \%$ & 0 & 0 & \\
\hline & & 20 & $100 \%$ & 0 & 0 & \\
\hline \multirow[t]{21}{*}{2.} & Masyarakat: & 1 & $70 \%$ & 0 & $30 \%$ & \\
\hline & & 2 & $100 \%$ & 0 & 0 & \\
\hline & & 3 & $100 \%$ & 0 & 0 & \\
\hline & & 4 & $100 \%$ & 0 & 0 & \\
\hline & & 5 & $100 \%$ & 0 & 0 & \\
\hline & & 6 & $100 \%$ & 0 & 0 & \\
\hline & & $?$ & $100 \%$ & 0 & 0 & \\
\hline & & 8 & $100 \%$ & 0 & 0 & \\
\hline & & 9 & $100 \%$ & 0 & 0 & \\
\hline & & 10 & $100 \%$ & 0 & 0 & $10=55,6 \%$ \\
\hline & & 11 & $100 \%$ & 0 & 0 & \\
\hline & & 12 & $100 \%$ & 0 & 0 & \\
\hline & & 13 & $100 \%$ & 0 & 0 & \\
\hline & & 14 & $100 \%$ & 0 & 0 & \\
\hline & & 15 & $100 \%$ & 0 & 0 & \\
\hline & & 16 & $100 \%$ & 0 & 0 & \\
\hline & & 17 & $100 \%$ & 0 & 0 & \\
\hline & & 18 & $100 \%$ & 0 & 0 & \\
\hline & & 19 & $100 \%$ & 0 & 0 & \\
\hline & & 20 & $100 \%$ & 0 & 0 & \\
\hline & Junlah: & & 98,346 & 0 & $1,7 \%$ & $18=100 \%$ \\
\hline
\end{tabular}

Kedua, respon terbuka yang masuk dari kelompok masyarakat $(\mathrm{X})$ yaitu : Satu, materi dan penjelasan yang disampaikan menarik sebab, menambah pengetahuan dan gampang dicerna. Sedangkan solusi yang disampaikan menarik sebab, mendapatkan pemecahan, dan tidak terlalu serius. Demikian video yang disampaikan menarik sebab, adanya penjelasan, dan bisa mengetahui dan membandingkan. Begitupun diskusi yang sudah dilakukan menarik sebab, tambah pengalaman, dan tidak terlalu serius.; Dua, adapun pengertian yang dipahami yaitu bahwa, maksud pemberdayaan tokoh masyarakat dan adat sebagai media komunikasi harmonis dan pembangunan masyarakat desa Sawarna Kabupaten Lebak Banten untuk

Ekonomi, Sosial, dan Budaya

1375 
memperkuat persaudaraan. Alasan pemberdayaan tersebut dilakukan karena punya wibawa atau kebijakan yang baik, sebagai cara untuk memajukan daerah desa Sawarna Kabupaten Lebak Banten, dapat berfungsi sebagai komunikator pembangunan, atau kepanjangan tangan dari Pemerintah karena buat menampung aspirasi, dan sebagai penampung yang mempertimbangkan segala keluhan dari masyarakat karena tokoh masyarakat lebih cocok. Selain itu mereka juga paham bahwa, tokoh masyarakat dan adat harus paham hakikat komunikasi dan mahir secara praktek, sebab mereka dianggap bisa bicara kepada masyarakat dan dituruti. Begitupun tentang budaya desa harus dipahami, namun harus punya sikap yang lebih toleran, karena budaya memperkuat ketahanan desa. Selain itu, harus paham dan sabar pada proses komunikasi, karena mereka dipilih sebab punya kelebihan. Juga sangat disarankan agar punya strategi komunikasi, yaitu strategi persuasi dan instruksi, karena dapat untuk mempersatukan masyarakat, serta harus kreatif dalam memilih saluran komunikasi karena harus punya seni. Hal lainnya yaitu, tentang alasan mengapa tokoh masyarakat dan adat harus diberdayakan yaitu karena, sebagai media komunikasi harmonis dan pembangunan masyarakat desa melalui hubungan (relasional) komunikasi antar para komunikator dalam berbagai setting, karena yang dipilih harus bisa mengurus dan menyatukan. adapun respon lain yang masuk yaitu bahwa, tokoh masyarakat dan adat harus paham prinsip pertukaran sosial (sosial exchange), agar masyarakat pendatang merasa nyaman. Juga harus paham prinsip kerja kelompok sebagai cara untuk memajukan daerah, dan harus paham langkah proses pemecahan masalah sebagai cara untuk menyatukan. Adapun respon lain yang masuk yaitu, peserta setuju dengan materi dan penjelasan yang disampaikan karena, bisa dimengerti, bisa buat perbandingan antar daerah, dan bisa tahu / menambah pengetahuan.

Adapun hasil yang diketahui melalui metode focus group discusion (FGD) selama 30 menit, sebagai cara untuk mengetahui pemahaman dan penerimaan peserta, yaitu sebagai berikut : Pertama, masyarakat Desa Sawarna Kabupaten Lebak Banten belum memiliki forum komunikasi adat, sehingga forum komunikasi adat tidak dapat diberdayakan.; Kedua, video tentang Desa Ponggok yang ditayangkan fasilitator sebagai contoh perbandingan dan cara untuk memotivasi peserta, mampu menarik perhatian semua peserta PKM, dan ternyata belum diketahui oleh semua peserta yang hadir.; Ketiga, penggunaan Video sebagai contoh dan alat bantu penjelasan, sangat mendukung dan disukai oleh semua peserta.; Keempat, adanya keluhan tentang Pemerintah desa setempat, seperti tentang dana Desa yang dinilai tidak transparan, masyarakat desa yang kurang diberdayakan oleh pemerintah desa, dan Pemerintah desa setempat dianggap pelit serta tidak peduli pada kegiatan masyarakat, komunitas pemuda, dan komunitas pariwisata desa Sawarna Kabupaten Lebak Banten. Selain itu, tidak adanya Badan Usaha Milik Desa (BUMDes) Sawarna, sebagaimana telah ditegaskan oleh Presiden Jokowidodo.

Demikian antara lain respon yang disampaikan secara tegas oleh peserta yang hadir. Bahkan pada akhirnya, mereka juga mengharapkan agar dalam kegiatan PKM berikutnya, para perangkat desa Sawarna juga bisa diundang, dan adanya forum dialog yang dapat menjadi jembatan komunikasi antara masyarakat desa Sawarna dengan Pemda Kabupaten Lebak Banten, agar apa yang dirasakan dan diharapkan oleh masyarakat desa Sawarna dapat diketahui dan diwujudkan.

\section{Sub Bab Pembahasan}

\subsection{Pembahasan}

Pertama, tentang pemahaman akan kebijakan pembangunan desa Sawarna. Ternyata semua peserta yang hadir belum mengetahui dan bagi mereka pembangunan desa Sawarna berjalan lamban, tidak dirasakan, tidak ada perubahan dan peningkatan kualitas kehidupan sosial ekonomi ke arah yang lebih baik dan wajar dari waktu ke waktu, serta belum merata. Demikian halnya dengan arah kebijakan pembangunan sektoral dan pemberdayaan masyarakat (people empowering) desa, tidak mereka ketahui. Menurut mereka, pemerintah desa tidak punya perhatian dan pembangunan desa belum bersifat multisektoral. Itulah sebabnya, para peserta masih belum tahu tentang metode dan program pembangunan masyarakat desa mereka, dan tidak

Ekonomi, Sosial, dan Budaya 1376 
aneh bila kesadaran gerakan masyarakat desa dalam melaksanakan pembangunan untuk meningkatkan kehidupan yang lebih baik masih lemah. Selain itu, menurut peserta yang hadir, pemerintah desa maupun kabupaten belum mengajak serta ataupun memberdayakan masyarakat desa Sawarna dalam pelaksanaan pembangunan daerah. Padahal keterlibatan masyarakat desa juga merupakan salah satu syarat mutlak dalam era kebebasan dan keterbukaan. Padahal menurut pengakuan para peserta, masyarakat desa Sawarna juga bersedia menjadi pemeran utama dalam mengimplementasikan program pembangunan di daerahnya. Jadi menurut para peserta yang hadir, harusnya penekanan tentang pemberdayaan tokoh masyarakat dan forum komunikasi adat sebagai media harmonis dan pembangunan masyarakat Desa Sawarna Lebak Banten juga disampaikan pada Pemerintah Desa Sawarna dan Pemda Lebak Banten.

Kedua, tentang pemahaman akan pemberdayaan masyarakat desa Sawarna. Menurut peserta yang hadir, terutama dari para tokoh masyarakat, banyak tokoh masyarakat desa Sawarna yang punya inisiatif dan kreatifitas yang tinggi. Namun karena belum pernah mendapatkan dukungan secara finansial maupun lain-lain, sehingga inisiatif dan krreatif tersebut akhirnya kembali mentah. Bahkan menurut mereka, masyarakat desa Sawarna tidak dan belum pernah mempunyai forum komunikasi adat, karena tidak mempunyai ketua adat. Jadi artinya, pemberdayaan forum komunikasi adat sebagaimana tema dalam kegiatan PKM ini tidak dapat diaplikasikan. Bahkan ketika ditanyakan tentang siapa yang bertindak sebagai komunikator pembangunan yamg menampung dan mempertimbangkan segala keluhan dari masyarakat, bagi mereka hampir tidak ada, kecuali RT atau RW saja. Namun menurut RT dan RW, mereka juga tidak dapat berbuat apa-apa, selain hanya menjadi pendengar yang baik saja, karena mereka juga tidak mempunyai kekuatan finansial dan sebagainya. Oleh karena itu, pada masyarakat desa Sawarna, tokoh masyarakat dan forum masyarakat adat belum dianggap sebagai perpanjangan tangan pemerintah. Selain itu, bagi masyarakat desa Sawarna, tokoh masyarakat, forum masyarakat adat, maupun pemerintah desa Sawarna, dianggap belum memiliki kepekaan serta kemampuan untuk dapat memberi respon, terhadap inisiatif dan keluhan yang berasal dari tingkat bawah. Dengan kata lain, menurut para peserta, keluhan masyarakat bawah seringkali diabaikan pemerintah Desa Sawarna. Untungnya masyarakat desa Sawarna belum pernah mengambil jalan pintas seperti melakukan pengrusakan ataupun hal-hal yang anarkhis.

Ketiga, tentang pemahaman akan pengertian komunikasi. Pada dasarnya ketika ditanyakan tentang pengertian dan manfaat komunikasi, semua peserta sudah tahu. Namun untuk menjelaskan secara ilmiah, tentang pengertian komunikasi, mereka belum mampu. Meski demikian, pada akhir ceramah, semua peserta tahu dan sepakat bahwa komunikasi adalah penting dan dapat untuk menyatukan masyarakat, serta membangun masyarakat desa Sawarna.

Keempat, tentang pemahaman akan hubungan komunikasi dan budaya. Pada masyarakat desa Sawarna, umumnya komunikasi dan budaya dilakukan dengan menggunakan bahasa dan budaya Sunda, tepatnya dengan bahasa dan budaya Banten. Sehingga sikap toleran juga masih tampak kuat. Meskipun sayangnya juga ada yang digunakan untuk hal yang tidak baik. Seperti banyaknya para pengendara roda dua yang tidak memakai helm dan tidak tertib berlalu lintas, namun kurang mendapatkan perhatian dari Polisi dan tokoh masyarakt setempat. Padahal harusnya sikap toleran terhadap pelanggaran budaya tertib berlalu lintas tidak boleh ada, karena dapat menyebabkan ketidaktertiban berlalu lintas, dan mengganggu para wisatawan yang datang ke desa Sawarna. Bahkan bisa juga mengakibatkan kecelakaan lalu lintas bagi siapapun juga. Jadi budaya tertib berlalu lintas pada masyarakat desa Sawarna masih lemah, dan kurang dikomunikasikan.

Kelima, tentang pemahaman akan proses komunikasi. Bagi peserta PKM, tokoh masyarakat dan forum komunikasi adat harus paham dan sabar pada proses komunikasi, karena tokoh masyarakat sebagai penyalur aspirasi, yang memberikan contoh kesabaran serta keramahan, dan dipilih karena punya kelebihan. Jadi artinya, meski proses komunikasi adalah sebuah hal yang sulit, namun sudah seharusnya dapat dipahami oleh para tokoh masyarakat desa Sawarna.

Ekonomi, Sosial, dan Budaya 
Keenam, tentang pemahaman akan dua bentuk strategi komunikasi seperti strategi persuasi dan strategi instruksi, seperti dijelaskan oleh Cutlip, Center, dan Broom (2006:229). Tidak dapat dijelaskan, karena peserta yang hadir tidak mampu menjelaskan tentang strategi persuasi yang mereka gunakan, dan karena mereka tidak merasa ada komunikasi yang baik dan dekat dengan pemerintah desa Sawarna. Namun setelah fasilitator menjelaskan bentuk-bentuk strategi persuasi dan strategi instruksi seperti dijelaskan Cutlip, Center, dan Broom, mayoritas peserta yang hadir dapat menerima, mengerti, dan terjadi perubahan pengetahuan. Salah satunya dapat dilihat dari hasil kuesioner seperti tampak pada Tabel 3. Demikian halnya tentang strategi komunikasi yang efektif. Sampai saat ini, menurut para peserta yang hadir, belum ada strategi komunikasi yang efektif antara mereka dengan pemerintah desa Sawarna. Sehingga bagi masyarakat dan tokoh masyarakat desa Sawarna, fungsi komunikasi antara mereka dengan pemerintah desa Sawarna belum mempunyai "fungsi ganda". Jadi, bagi masyarakat dan tokoh masyarakat desa Sawarna, masih ada kesenjangan komunikasi (communication gap).

Ketujuh, tentang pemahaman akan teknik persuasi atau membujuk, seperti dikemukakan oleh Cutlip, Center, dan Broom (hal.228). Menurut mereka, belum pernah dirasakan, karena pemerintah desa belum pernah mengajak mereka berdialog, berunding ataupun bermusyawarah secara langsung tentang pembangunan desa dan pemberdayaan masyarakat maupun tokoh masyarakatnya. Padahal ada banyak isu, kecurigaan, dan konflik antara yang pro dan kontra. Jadi artinya, dialog antara pemerintah desa dan tokoh masyarakat serta masyarakat desa Sawarna belum terjalin dengan baik. Dengan kata lain, pemerintah desa Sawarna, belum memanfaatkan forum dialog sebagai cara untuk memberdayakan tokoh masyarakat dan masyarakat desa Sawarna, ataupun sebagai cara untuk membangun resistensi (antipati) terhadap pesan yang datang belakangan.

Kedelapan, tentang pemahaman akan saluran komunikasi, baik bersifat medium (tunggal) ataupun media (jamak), seperti dikemukakan oleh Cutlip, Center, dan Broom (hal.230). Dari berbagai bentuk medium yang disampaikan fasilitator, masyarakat dan tokoh masyarakat desa Sawarna mengganggap rapat maupun gotong royong merupakan medium yang paling mudah dilakukan. Sedangkan radio desa, mereka belum memilikinya. Demikian panggung rakyat, mereka juga belum memilikinya. Buktinya di desa Sawarna belum ada alun-alun tempat pementasan kesenian rakyat.

Kesembilan, tentang pemahaman akan hubungan (relasional) komunikasi. Seperti dikemukakan oleh Cutlip, Center, dan Broom (hal.232), komunikasi terjadi di dalam konteks hubungan para komunikator, dan rentang hubungan itu mencakup hubungan dekat (intim), hubungan formal, hubungan kompetitif, dan hubungan interpersonal konfliktual dalam berbagai setting, yang juga sangat mempengaruhi proses komunikasi. Dari hasil diskusi dapat dipahami bahwa, hubungan (relasional) komunikasi antar masyarakat dengan tokoh masyarakat dan Pemerintah desa Sawarna, masih bersifat atau masuk kategori hubungan kompetitif, bukan dekat apalagi intim. Sehingga dimensi ketundukkan diantara mereka, masih belum kental. Namun demikian, juga tidak nampak adanya hubungan yang bersifat kompetitif apalagi konfliktual secara interpersonal.

Kesepuluh, tentang pemahaman akan empat (4) dimensi dasar hubungan komunikasi. Seperti dikemukakan oleh Cutlip, Center, dan Broom (hal.232), dan seperti telah dijelaskan dalam pembahasan kesembilan, maka dapat dipahami bahwa, bila dilihat dari pekspektif dimensi dasar hubungan komunikasi antar masyarakat dengan tokoh masyarakat dan Pemerintah desa Sawarna, yaitu sebagai berikut : masih belum tampak adanya hubungan komunikasi yang bersifat akrab, sebagai akibat masih lemahnya rasa suka. Demikian tentang sentuhan, dialog, dan keterbukaan dalam penyampaian perasaan emosional mereka, masih tampak lemah. Begitu juga tentang kedekatan (proximity), daya tarik, kepercayaan, perhatian, dominasi, persuasi, dan keagresifan, juga masih kurang. Tentu saja hal ini menjadi hambatan bagi pemberdayaan tokoh masyarakat dan forum komunikasi adat sebagai media harmonis pembangunan desa Sawarna. Hal lain yang diketahui dari hasil tanya jawab dalam diskusi kelompok dengan peserta PKM yaitu, belum adanya kegiatan yang dilakukan secara bersama yang Ekonomi, Sosial, dan Budaya 1378 
menggambarkan kegemaran antar masyarakat dengan tokoh masyarakat dan Pemerintah desa Sawarna, sebagai salah satu cara pemberdayaan tokoh masyarakat dan forum komunikasi adat sebagai media harmonis pembangunan desa Sawarna. Misalnya saja seperti kegiatan mancing bersama antar tokoh masyarakat, ataupun wisata sepeda gembira, menurut penjelasan para peserta yang hadir, juga tidak pernah dilakukan. Namun meski demikian, menurut penjelasan peserta yang hadir, mereka tetap menaruh hormat kepada para tokoh masyarakat dan pemerintah desa Sawarna, misalnya saja saat mengucapkan kata-kata kepada yang terhormat, ataupun saat menempatkan tokoh masyarakat dalam barisan tempat duduk, sebagai cara menunjukkan sikap hormat. Jadi artinya, masih ada dominasi ketundukan masyarakat terhadap para tokoh masyarakat dan pemerintah desa Sawarna. Seharusnya hal tersebut dapat dimanfaatkan oleh tokoh masyarakat dan pemerintah desa Sawarna. Khususnya untuk kepentingan pembangunan desa Sawarna. Misalnya saja tentang konsep homestay bagi para wisatawan domestik maupun internasional, tertib berlalu lintas, kebersihan dan keindahan lingkungan desa Sawarna, dan sebagainya yang mampu membuat desa Sawarna sebagai desa wisata terkenal dan maju di negri ini.

Kesebelas, tentang pemahaman akan prinsipprinsip yang harus diperhatikan agar khalayak atau kelompok masyarakat yang diajak berdialog melalui forum komunikasi adat mau diajak bekerjasama. Seperti diketahui, sebagaimana dijelaskan oleh Thibaut dan Kelly, (Goldberg dan Larson, 1985:54) dalam Teori Pertukaran Sosial, interaksi antar manusia bagaikan konsep transaksi dagang, yang fokus pada pertukaran barang dan jasa. Jadi menurut teori ini, hubungan baik akan terus terjaga bila masing-masing pihak merasa diuntungkan dari hubungan tersebut. Dalam arti, pada dasarnya setiap orang akan mengharapkan sesuatu dari orang lain sebagai cara untuk memenuhi kebutuhannya. Jadi adalah wajar bila tanggapan-tanggapan antar individu yang muncul melalui interaksi di antara mereka juga akan mencakup baik imbalan (reward), pengorbanan (cost), maupun keuntungan (profit). Demikian halnya dalam hubungan antar masyarakat, tokoh masyarakat, dan pemerintah desa Sawarna. Namun menurut penjelasan semua peserta yang hadir, mereka belum merasakan hal tersebut. Bahkan menurut mereka, pemerintah desa Sawarna belum peduli secara materi. Contohnya saja, mereka belum pernah menerima bantuan dana segar untuk berbagai proposal acara yang mereka tawarkan. Padahal menurut mereka, kegiatan tersebut juga untuk kepentingan promosi desa Sawarna. Jadi dapat dipahami, interaksi maupun hubungan baik antar masyarakat, tokoh masyarakat, dan pemerintah desa Sawarna kurang terjaga, sebab masih ada pihak yang merasa kurang diuntungkan dari hubungan tersebut. Hal ini sangat tampak dari berbagai tanggapan peserta yang hadir. Mayoritas peserta sangat menekankan kurangnya imbalan (reward), pengorbanan (cost), maupun keuntungan (profit) yang mereka rasakan dari pemerintah desa Sawarna. Jadi artinya, pemerintah desa Sawarna masih lemah dalam memberikan perhatian seperti imbalan (reward), pengorbanan (cost), maupun keuntungan (profit) pada mayoritas masyarakat desa Sawarna, yang juga mempengaruhi upaya pemberdayaan tokoh masyarakat dan forum komunikasi adat sebagai media harmonis dan pembangunan masyarakat desa Sawarna. Jadi adalah tepat kegiatan PKM ini dilakukan di desa Sawarna, selain sebagai solusi yang perlu disampaikan, juga agar para tokoh masyarakat dan forum komunikasi adat dapat diberdayakan sebagai media komunikasi harmonis dan pembangunan bagi masyarakat Desa Sawarna, Lebak, Banten. Selain itu juga agar prinsip imbalan dan keuntungan bagi para tokoh masyarakat dan forum komunikasi adat serta masyarakat desa Sawarna dapat dipahami, sehingga para tokoh masyarakat dan forum komunikasi adat dapat diberdayakan sebagai media komunikasi harmonis dan pembangunan masyarakat desa Sawarna.

Keduabelas, tentang pemahaman akan komunikasi efektif untuk komunikasi kelompok yang bersifat heterogen atau multikultural. Sebagaimana dikutip dari Teori Kerja Kelompok Efektif Antarbudaya seperti dikemukakan oleh John Oetzel (Littlejohn, 2009:336) yaitu tentang adanya kesetaraan diantara partisipan (partisipasi setara), mufakat berdasarkan pengambilan keputusan, manajemen konflik yang tidak mendominasi, dan komunikasi dengan penuh hormat. Menurut penjelasan para peserta PKM, yang terdiri dari tokoh masyarakat dan masyarakat biasa, belum adanya partisipasi setara dan mufakat berdasarkan

\begin{tabular}{l|l} 
Ekonomi, Sosial, dan Budaya & 1379
\end{tabular} 
pengambilan keputusan bersama antar masyarakat, tokoh masyarakat, dan pemerintah desa Sawarna. Bahkan menurut mereka, pemerintah desa masih sangat mendominasi dan kurang menaruh hormat pada masyarakat maupun tokoh masyarakat desa Sawarna. Jadi dapat dipahami, komunikasi yang dilakukan oleh pemerintah desa Sawarna masih belum efektif, dan inilah salah satu penyebab masih belum berkembangnya pembangunan di desa Sawarna.

Ketigabelas, tentang pemahaman akan enam langkah proses pemecahan masalah antar masyarakat, tokoh masyarakat, dan pemerintah desa Sawarna. Sebagaimana dikemukakan oleh John Dewey (1910) dalam Teori Fungsional (Littlejohn, hal.344), diungkapkan bahwa, mengungkapkan kesulitan, menjelaskan permasalahan, menganalisis masalah, menyarankan solusi, membandingkan alternatif dan menguji mereka dengan tujuan dan kriteria yang berlawanan, serta mengamalkan solusi yang terbaik, adalah enam langkah proses pemecahan masalah. Namun ketika hal ini disampaikan dan didiskusikan, spontan para peserta memberikan respon bahwa hal tersebut tidak pernah berhasil mereka lakukan, terutama dalam memecahkan masalah dengan pemerintah desa Sawarna. Menurut mereka, pada tahap pertama yaitu untuk mengungkapkan kesulitan saja sudah sulit. Apalagi untuk tahap selanjutnya. Jadi dapat dipahami bahwa, bila demikian, ada banyak masalah antar masyarakat, tokoh masyarakat, dan pemerintah desa Sawarna yang belum dapat dipecahkan, akibat belum dilaksanakannya enam langkah proses pemecahan masalah seperti dijelaskan oleh John Dewey (1910).

\section{KESIMPULAN}

Kegiatan ini berjalan dengan baik, lancar, menarik dan menyenangkan bagi semua peserta yang hadir. Secara garis besar, diperoleh simpulan sebagai berikut :

Pertama, dari duapuluh satu peserta yang hadir, sekitar 55,6\% peserta yang hadir berasal dari kelompok masyarakat biasa, dan $44 \%$ merupakan tokoh masyarakat. Paling banyak memiliki latarbelakang pendidikan SD yaitu 44,5\%, SLTP dan SLTA masing-masing 22,2 \%, dan sisanya 11,1 $\%$ memiliki latarbelakang pendidikan S-1. Namun meski mayoritas peserta yang hadir tidak memiliki latarbelakang pendidikan yang tinggi, tetapi tingkat perhatian dan ketertarikan mereka terhadap isi pesan yang disampaikan fasilitator sangat tinggi, mencapai 96,9\%. Demikian halnya tentang tingkat pengertian peserta terhadap isi pesan sosialisasi juga tinggi, mencapai $97 \%$. Begitu juga halnya dengan penerimaan peserta akan isi pesan sosialisasi juga tinggi, mencapai 98,3\%. Sedangkan tentang respon terbuka peserta, meski tidak semua peserta memberikan respon terbuka, namun respon yang diterima semua bernilai positif dan memperlihatkan adanya komunikasi yang aktif dari para peserta PKM. Demikian halnya tentang penggunaan Video sebagai contoh dan alat bantu penjelasan, dari respon yang diberikan ternyata sangat mendukung dan disukai, bahkan mampu menarik perhatian semua peserta PKM.

Kedua, dari hasil focus group discusion (FGD) selama 30 menit dapat diketahui bahwa, masyarakat desa Sawarna Kabupaten Lebak Banten belum memiliki forum komunikasi adat, sehingga forum komunikasi adat tidak dapat diberdayakan. Hal ini dikarenaan, di desa Sawarna tidak ada tokoh adat. Selain itu, tingginya keluhan tentang Pemerintah desa setempat, mulai dari permasalahan tentang dana Desa yang dinilai tidak transparan, kurangnya pemberdayaan masyarakat desa Sawarna Kabupaten Lebak Banten oleh pemerintah desa, dan kurangnya perhatian secara finansial oleh pemerintah desa setempat terhadap kegiatan masyarakat seperti komunitas pemuda, maupun komunitas pariwisata desa Sawarna Kabupaten Lebak Banten. Juga tidak adanya Badan Usaha Milik Desa (BUMDes) Sawarna, sebagaimana telah ditegaskan oleh Presiden Jokowidodo. Pada akhirnya, para peserta PKM juga sangat mengharapkan adanya kegiatan PKM berikutnya bersama para perangkat desa Sawarna dan Pemda Kabupaten Lebak Banten, dengan harapan agar adanya forum dialog yang dapat menjadi jembatan komunikasi antar masyarakat, dan tokoh masyarakat desa Sawarna dengan Pemda Kabupaten Lebak Banten, agar apa yang dirasakan dan diharapkan oleh masyarakat desa Sawarna dapat diketahui dan diwujudkan.

Ekonomi, Sosial, dan Budaya 1380 
Ketiga, masih banyak masalah dalam hubungan antar masyarakat, tokoh masyarakat, dan pemerintah desa Sawarna, maupun Pemda Kabupaten Lebak Banten. Diantaranya karena kurangnya imbalan (reward), pengorbanan (cost), maupun keuntungan (profit) dari pemerintah desa Sawarna dan Pemda Kabupaten Lebak Banten. Sehingga besar kemungkinan, pemberdayaan masyarakat dan forum komunikasi adat sebagai media harmonis dan pembangunan masyarakat desa Sawarna hanya masih sebatas wacana dan belum dapat diterapkan secara maksimal. Jadi besar kemungkinan, perubahan dan peningkatan kualitas kehidupan sosial ekonomi masyarakat desa Sawarna akan berjalan lamban, dan pembangunan di desa Sawarna masih belum merata. Demikian halnya dengan arah kebijakan pembangunan sektoral dan pemberdayaan masyarakat (people empowering) desa, juga belum dipahami masyarakatnya. Hal ini juga diakibatkan masih adanya kesenjangan komunikasi (communication gap), sebagai akibat belum adanya forum dialog yang baik antar masyarakat, tokoh masyarakat, pemerintah desa Sawarna, dan Pemda Kabupaten Lebak Banten. Jadi artinya, dialog. Dengan kata lain, pemerintah desa Sawarna, belum memanfaatkan forum dialog sebagai cara untuk memberdayakan tokoh masyarakat dan masyarakat desa Sawarna, ataupun sebagai cara untuk membangun resistensi (antipati) terhadap pesan yang datang belakangan. Demikian panggung rakyat, mereka juga belum memilikinya. Buktinya di desa Sawarna belum ada alun-alun tempat pementasan kesenian rakyat. Adapun tentang hubungan (relasional) komunikasi antar masyarakat dengan tokoh masyarakat dan Pemerintah desa Sawarna, masih bersifat atau masuk kategori hubungan kompetitif, bukan dekat apalagi intim. Sehingga dimensi ketundukkan diantara mereka, masih belum kental. Namun demikian, juga tidak tampak adanya hubungan yang bersifat kompetitif apalagi konfliktual secara interpersonal. Dalam arti, masyarakat desa Sawarna masih tetap dapat menaruh hormat dan tunduk kepada para tokoh masyarakat dan pemerintah desa Sawarna, termasuk Pemda Kabupaten Lebak Banten, meskipun bagi mereka pemerintah desa masih sangat mendominasi dan kurang menaruh hormat pada masyarakat maupun tokoh masyarakat desa Sawarna.

\section{UCAPAN TERIMAKASIH}

Ungkapan terima kasih disampaikan kepada Lembaga P2M Universitas Mercu Buana dan Kelompok Sadar Wisata Desa Sawarna, karena telah berkenan hadir dan sangat terbuka dalam acara ini.

\section{REFERENSI}

Cutlip, Scott M., dan Center, Allen H., serta Broom, Glen M. (2016), Effective Public Relations, Edisi Kesembilan, Jakarta : Penerbit Prenadamedia Group.

Devito, Joseph A. (2009). Human Communication. Printed In The United States Of America : Pearson Education

Effendi, Onong Uchjana. 2003. Ilmu, Teori Dan Filsafat Komunikasi. Bandung : Citra Aditya Bakti

Littlejohn, Stephen W. 2008. Theories Of Human Communication. Printed In The United States Of America : Thomson

Rosmawaty. H.P., (2010), Mengenal Ilmu Komunikasi. Bandung : Widya Padjadjaran

Kholil, Syukur., Sahrul., dan Diaurrahman., (2017). Peran Komunikasi Pembangunan Badan Pemberdayaan Masyarakat (BPM) Dalam Pembangunan Sosial dan Keagamaan Di Kota Langsa, Jurnal Al-Balagh, Vol. 1 No. 2 JuliDesember 2017: 291-301, file:///E:/PENGABDIAN \%20PADA\%20MASYARAKAT/PKM\%20Lebak \%202018-19/1490-3657-1-SM.pdf, diakses hari Rabu, 14 November 2018, pk. 02:50 wib

Putri, I Dewa Ayu Hendrawathy. (2018), Strategi Komunikasi Penguatan Peran Adat dalam Menjaga Lingkungan berlandaskan Falsafah Tri Hita Karana di Desa Batuan Kecamatan Sukawati Kabupaten Gianyar Bali, Jurnal Widya Duta, Vol. XIII, No. 1, file:///E:/PENGABDIAN\%20PADA\% 20MASYARAKAT/PKM\%20Lebak\%20201819/434-795-1-SM.pdf, dikases hari Rabu, 14 November 2018, pk. 02:30 wib.

Sthepanie, Yessie. (2015), Strategi Pengembangan Fasilitas Wisata Pantai Sawarna Di Kabupaten Lebak Banten , diakses dari 
Prosiding PKM-CSR, Vol. 2 (2019)

e-ISSN : 2655-3570

repository.upi.edu, perpustakaan.upi.edu, file:///E:/PENGABDIAN\%20PADA\%20MASYAR AKAT/PKM\%20Lebak\%202018-19/SMRL110175
0_Chapter1.pdf, dikases hari Rabu, 14 November 2018, pk. 00:30 wib. 